\title{
MULTICULTURAL COMPETENCE OF PROSPECTIVE PRESCHOOL TEACHERS IN PREDOMINANTLY MUSLIM COUNTRY
}

\author{
M. Solehuddin* \& Nandang Budiman \\ Universitas Pendidikan Indonesia, Indonesia \\ *e-mail: msolehuddin@upi.edu
}

\begin{abstract}
Prepared to teach young children in a multi-ethnic and religious society like in Indonesia, the prospective preschool teachers should have strong belief and practice in social justice and multiculturalism. However, this quality is not easily achievable by prospective teachers from ethnic and religious majority group, like Indonesian Muslim prospective preschool teachers who may have limited awareness and exposure to multicultural diversity. This study identified some existing multicultural competences of the participants before designing a training model to prepare prospective preschool teachers, to develop their multicultural competence. Data for this study were derived from the questionnaire and interview which reveal awareness, knowledge, and skill dimensions of multicultural competence. Findings show that the majority of the participants have a high level of multicultural awareness and indicate a difference of multicultural competence among different levels of students. Based on these findings and expert judgments, the study designs a training model to develop prospective preschool teachers' multicultural competence which has the following sequence: systematic reflection, Socratic dialog, simulation, field practice, and reflection. The study also provides some recommendations on the inclusion of multicultural content into intracurricular and/or extracurricular activities as well as on testing and analyzing the effectiveness of the hypothetical training model resulted from this study.
\end{abstract}

Keywords: preschool teachers, multicultural competence, predominantly muslim prospective

\section{KOMPETENSI MULTIKULTURAL CALON GURU PAUD DI NEGARA MAYORITAS MUSLIM}

\begin{abstract}
Abstrak: Dipersiapkan untuk mengajar anak-anak yang berasal dari masyarakat multi-etnis dan agama seperti di Indonesia, calon guru PAUD perlu memiliki pemahaman dan pengalaman yang memadai tentang masalah keadilan sosial dan multikulturalisme. Namun, kompetensi ini tidak mudah untuk dikuasai oleh calon guru yang berasal dari kelompok etnis mayoritas seperti calon guru Muslim di Indonesia yang memiliki kesadaran terbatas akan perbedaan multikultural. Penelitian ini mengidentifikasi kompetensi multikultural calon guru PAUD sebelum merancang suatu model pelatihan untuk menyiapkan calon guru PAUD untuk mengembangkan kompetensi multikultural. Data penelitian diperoleh dari angket dan wawancara untuk mengungkap dimensi kesadaran, pengetahuan, dan keterampilan dari kompetensi multikultural. Temuan penelitian menunjukkan bahwa kebanyakan peserta memiliki kompetensi multikultural yang tinggi dan mengindikasikan adanya perbedaan kompetensi multikultural antara angkatan yang berbeda. Berdasarkan temuan ini serta pertimbangan ahli, penelitian ini menghasilkan rancangan sebuah model pelatihan pengembangan kompetensi multikultural untuk para calon guru PAUD yang mencakup refleksi sistematis, dialog Socratic, simulasi, praktik lapangan, dan refleksi. Penelitian juga merekomendasikan dimasukkannya materi multikulturalisme ke dalam kurikulum pembelajaran di sekolah dan ekstra-kurikuler serta perlunya pengujian efektivitas model pelatihan hipotetis yang dihasilkan dari studi ini.
\end{abstract}

\section{Kata Kunci: guru PAUD, kompetensi multikultural, negara mayoritas muslim}

\section{INTRODUCTION}

Since today's world becomes more culturallydiverse, all humaninteraction, including education, should be more accommodative to social justice and equity. Nowadays, multiculturalism should be incorporated into the 2020 classroom teaching (Childs, 2017) as an effective learning strategy (Alfulailah, Haryadi, Sudrajat, \& Nasrullah (2019), and education should be directed to promote culturally 
responsive teaching as a principal pedagogy (Walter, 2018) with local policy of curriculum developed based on the cultural values (Ghufron, Budiningsih, \& Hidayati, 2017). In this era, human resources need to acquire new competencies completely different from the current ones (Wagiran, Pardjono, Suyanto, Sofyan, Soenarto, \& Yudantoko, 2019), even technology literacy has become an important identity of counselor's cultural competence (Farozin, 2019). In fact, issues of social justice and equity have recently also become a serious attention among scholars of early childhood education (Blodorn, O'Brien, Cheryan, \& Vick, 2016; Enoksen \& Sandal, 2015). This increasing concern for more social justice is more relevant for educators of preschool teachers in Indonesia, a multiethnic and culturally diverse community.

Indonesia is a good example of multicultural country. The archipelago is home to 1,128 local ethnicities inhabiting about 17,508 islands across the archipelago, speaking more than 700 ethnic languages (RoI, Setjen MPR RI, 2012). Without sufficient understanding of multiculturalism, as some scholars have hinted (Hays \& Erford, 2010; Kagnic1, 2011; Baruth \& Manning, 2012; Spanierman \& Poteat, 2005), the country may experience interethnic conflict and intercultural clash, as what has happened with a few cases of inter-ethnic clashes among local ethnic groups. Instead of creating more harmony, unresponsiveness to diversity may lead to social unrest (Norman, 2000). At regional level, the need for more culturally responsive preschool teachers is more salient with the establishment of ASEAN Economy Community in 2015.

Consequently, multicultural competence among educators becomes more necessary in multi-ethnic Indonesia. Teachers' acquisition of this competence enables children of different cultural backgrounds to live together in peace and harmony in the future (Hays \& Erford, 2010; Cates, Schaefle, Smaby, Maddux, \& Beauf, 2007; Jackson, 2006). For this reason, many studies have been conducted on the importance of multiculturally responsive teaching and pedagogy among majority teachers particularly White teachers among secondary schools in US and other White majority contexts (Cicchelli \& Cho, 2007; Villegas, 2007; Gay, 2010, 2013; Bonner, Warren, \& Jiang, 2018), including among preschool teachers (Perkins \& Mebert, 2005). However, the issue of multiculturally responsive teaching among non-White majority like the case of majority Muslim pre-service preschool teachers in Indonesia is still under study. This non-White majority is often ignored but actually important to address in non-White context. Besides, studies on majority or minority groups also focuses on in-service teachers and neglect pre-service teachers who will, in fact, teach in a more culturally diverse context.

Therefore, this study focuses on the awareness, knowledge and practice of multiculturally responsive teaching and pedagogy of the participating pre-service preschool teaching from a public university in Bandung, Indonesia. The majority issue in this study is not racial (white and non-white) but ethnical (majority and minority) and ideological (Islam as majority and non-Islam as minority).

However, most studies on the development of multicultural competence have focused on a correlational study between teachers' multicultural attitudes and practices (Linwood, Nicole, \& Donell, 2008; Bidell, 2012). These studies have not addressed teachers' development of these attitudes and practices. Considering the importance of developing teachers' multicultural competence as part of learning autonomy and sustainability, designing a training for developing preschool teachers' multicultural competence is deemed more necessary. The training should develop prospective teacher's awareness on the importance of their own cultural values and knowledge, personal sensitiveness to the cultural background of their future students as well as develop skills to appreciate and accommodate students' cultural background in their learning process for more harmonious diversity (Gay, 2010; Baruth \& Manning, 2012). The development of multicultural competence should also include multicultural social desirability, ethnic identity development, self-efficacy to multicultural encounters, and multicultural empathy (Hays \& Erford, 2010).

Based on the above mentioned discussion on multicultural competence and multiculturally responsive attitudes among predominantly participating Muslim preschool teachers, the study formulates the following questions. What is the participants' multicultural competence and 
Table 1. Inter-Cohort Multicultural Competence of Prospective Preschool Teachers

\begin{tabular}{lcccc}
\hline & \multicolumn{3}{c}{ Frequency } & Total \\
\cline { 2 - 4 } & Low & Medium & High & \\
\hline Year 2 & $0(.00 \%)$ & $9(21.95 \%)$ & $32(78.05 \%)$ & 41 \\
Year 3 & $0(.00 \%)$ & $8(20.51 \%)$ & $31(79.49 \%)$ & 39 \\
Year 4 & $0(.00 \%)$ & $1(2.33 \%)$ & $42(97.67 \%)$ & 43 \\
Total & $0(.00 \%)$ & $18(14.63 \%)$ & $105(85.37 \%)$ & 123 \\
\hline
\end{tabular}

Table 2. The Attainment of Participants in Aspects of Multicultural Competence

\begin{tabular}{llcccc}
\hline \multicolumn{1}{c}{ Aspects } & \multicolumn{1}{c}{ Dimensions } & Year 2 & Year 3 & Year 4 & Average \\
\hline $\begin{array}{l}\text { Awareness on values and bias } \\
\text { of one's own culture }\end{array}$ & Attitude and belief & $89.84 \%$ & $88.03 \%$ & $95.35 \%$ & $91.07 \%$ \\
& Knowledge & $82.44 \%$ & $84.62 \%$ & $92.09 \%$ & $86.38 \%$ \\
& Skill & $65.04 \%$ & $68.38 \%$ & $74.42 \%$ & $69.28 \%$ \\
Average & & $79.11 \%$ & $80.34 \%$ & $87.29 \%$ & $82.25 \%$ \\
$\begin{array}{l}\text { Awareness on values and bias } \\
\text { of other's culture }\end{array}$ & Attitude and belief & $84.15 \%$ & $79.49 \%$ & $83.72 \%$ & $82.45 \%$ \\
& Knowledge & $63.41 \%$ & $69.23 \%$ & $79.07 \%$ & $70.57 \%$ \\
& Skill & $78.05 \%$ & $82.05 \%$ & $86.05 \%$ & $82.05 \%$ \\
Average & & $75.20 \%$ & $76.92 \%$ & $82.95 \%$ & $78.36 \%$ \\
$\begin{array}{l}\text { Culturally responsive } \\
\text { interaction or learning } \\
\text { intervention strategy }\end{array}$ & Attitude and belief & $58.54 \%$ & $60.68 \%$ & $71.32 \%$ & $63.51 \%$ \\
& Knowledge & $62.06 \%$ & $65.82 \%$ & $73.90 \%$ & $67.26 \%$ \\
\hline Average & Skill & $56.62 \%$ & $56.60 \%$ & $59.967 \%$ & $57.73 \%$ \\
\hline Average of multicultural competence & $59.07 \%$ & $60.03 \%$ & $68.40 \%$ & $62.50 \%$ \\
\hline
\end{tabular}

More specifically, the attainment of participants' multicultural competence (in terms of percentage of mean score to maximum score) in aspects of attitude and belief, knowledge, and skills is presented in the Table 2 .

Table 2 shows that, in general, the participants have higher multicultural awareness of their own, followed by awareness of other cultures, and lower cultural response and interaction. It also seems that multicultural competence grows with age. As the table shows, the older the participating cohort, the higher the level of multicultural competence. One thing needs to note here is the skill dimension tends to be lower than the attitude-belief and knowledge ones.

Similar to the above finding, differential analysis of participants' multicultural competence through t-test at the significance level of $\alpha=.05$ indicating that while no difference between multicultural competence between year 2 and year 3 , year 4 is higher significantly than the both ones. 
how may a hypothetic training model prepare multiculturally responsive preschool teachers in predominantly Muslim majority Indonesia?

In this study, the multicultural competence is defined as a set of individual capacity to handle multicultural problems built up by (1) awareness and bias of his/her own values, (2) awareness and bias of others' (children's) culture, and (3) learning intervention strategy for culturally responsive teaching. Each of these aspects consists of three following dimensions: Attitudes and beliefs, knowledge, and skills.

\section{METHOD}

This study has two main purposes. Firstly is to analyze level and attainment of participants' multicultural competence; and secondly is to develop a hypothetical training model to prepare multiculturally responsive preschool teachers in predominantly Muslim majority Indonesia.

Participants of this study are three cohorts of participants (years 2, 3, and 4) of preschool teacher education program in a public university in Bandung, Indonesia. These last three year students were purposely selected on the assumption that years 3-4 students will finish their study and start teaching profession within a few years whereas the result from year 2 students served as an entry information on participants' multicultural knowledge. All participants (123 students) identified themselves as Muslims, the majority religion in Indonesia. Meanwhile, most participants identified themselves as Sundanese (63 students), Javanese (24 students), Batakese (16 students) and Minangese (20 students), the four major ethnicity groups in Indonesia.

Data for this study were derived from questionnaire on multicultural competence awareness. To obtain more comprehensive and rich data, the study also includes interviews with participants on necessary competence required in their multicultural teaching contexts, focus group discussion among participants and researchers, and expert judgments. The interviews were administered to explore the participants' existing and post knowledge on multicultural competence whereas the focus group discussion and expert judgments were used to seek an appropriate formulation of training model to develop participants' multicultural competence.
For confirmability purposes, results of interviews were cross-checked with the participants. Results of quantitative data on demography and cultural awareness were then triangulated with qualitative data of interviews to explore a more comprehensive account of participants' attitudes, knowledge and teaching skills of multicultural competence.

Based on questionnaire findings, supported by relevant literature on CRP, the study developed a hypothetical model for developing prospective pre-school teachers' multicultural competence. This hypothetical model was then validated through expert judgment.

For the purpose of classifying score, participants' scores were compared to the following criteria; High is equal to or more than Ideal Mean plus 0.67 Ideal Standard Deviation (one third of the Mean), Low is equal to or lower than Ideal Mean minus 0.67 Ideal Standard Deviation, and Medium is between the both. Next, to determine the attainment of participants' multicultural competence, data analysis was conducted by calculating percentage of mean score to maximum score. Finally, content analysis on qualitative data was carried out to enrich the study findings.

\section{FINDINGS AND DISCUSSION Findings}

Findings include description on participants' multicultural competence and their development followed by proposed model of training for the development of multicultural competence.

\section{Participants' multicultural competence}

The first finding was identified from questionnaire on participants' awareness of multicultural competence. Findings of intercohort participants of pre-service preschool teachers are shown in Table 1. This table shows that in general, the most of participants have high level of multicultural competence, few of them have medium level, and none of them has low level. Per cohort data show that year 4 students have more percentage of high level compared to two other lower cohorts, year 2 and year 3. 


\section{Proposed Model of Training for Multicultural Competence}

Based on findings of this study and referred conceptual framework, accompanied by expert judgments, this study proposes a hypothetical training model to prepare the multicultural competence of prospective preschool teachers. The model includes the development of awareness-belief, knowledge and skills (Cornish, Schreier, Nadkarni, Metzger \& Rodolfa, 2010). This training model consists of two parts: guideline and manual of multicultural awareness for pre-service teachers.

\section{Part 1. Guideline for training of multicultural competence}

The first part serves as a guideline for administering a training in multicultural competence among pre-school teachers. This guideline consists of four sections. The first section is an introduction which includes background, principles, objectives and aims. The second section includes concepts for multicultural training, consisting of paradigm, significance, core values, and context. The third section serves as the implementation of the training, including vision, mission, program, scenario, strategy, and quality assurance. The last section is conclusion, emphasizing the importance of training of multicultural competence for pre-school teachers.

\section{Part 2. Manual for training of multicultural competence}

The second part of the model is a manual book for administering the training for multicultural competence which include three phases and four strategies. The phases are assessment of multicultural competence, intervention for multicultural competence development, and reflection and further activity. Meanwhile, the strategies are systemic reflection, Socratic dialog, simulation, and field practice as described below.

Systematic reflection. This is in the form of brainstorming activity to identify participants' impression, knowledge, and critique on their own multicultural competence followed by a commitment to develop this competence. It serves as a personal, honest and productive reflection on how they develop and improve their knowledge, skills and competence of multicultural competence, facilitated by lecturers.

Socratic dialog. This dialog serves as a means to explore understanding, deepening, and developing students' multicultural competence through dialogic interaction in both individual and group modes. Socratic dialog enables prospective preschool teachers to develop their understanding and awareness of multiculturalism as majority group.

Simulation. This simulation process serves as a practice for developing students' multicultural competence through role plays with peers. In this simulation, students take turns playing as observers, pre-school teachers, and students' counselees.

Field practice. Field practice is a means of developing and sharpening students' strategies of multicultural competence through cultural understanding in authentic setting of schools or the multicultural society.

\section{Discussion}

An interesting finding of this study is the fact that most of participants have high level of multicultural competence, and just few of them have medium level and none of them has low one. This finding rejects the thinking that Muslim people are not or less tolerance in their attitudes and behaviors. We think that a narrow and rigid understanding of a religion (not only Islam) that could guide and direct people to be intolerant with others with different believes. Even, an appropriate and wide understanding on their belief could support them to live harmoniously with various people. In this case, we find that the participants of this study are students of a big university located in the capital city of West Java province. Their contextual lives could support them to experience rich interaction with many and various people. This complex and dynamic interaction, according to Cates, et al. (2007), could build their multicultural competence.

In line with aspects of multicultural competence analyzed in this study, further discussion is divided into three parts: awareness, knowledge and skills. Each part is described with relevant theories and some examples.

\section{Awareness of Multiculturalism}

The first aspect of multicultural competence is awareness. The finding above reveals 
some phenomena in relation to participants' multicultural awareness. First, as Table 1 shows, most prospective preschool teachers have high category of multicultural competence and only a few have medium level. Meanwhile, Table 2 also shows that, in general, the participating students have higher multicultural awareness of their own, followed by awareness of other cultures, and lower cultural response and interaction. It also seems that multicultural competence grows with age. As the table shows, the oldest participating cohort has higher level of multicultural competence than the both ones. In addition, percohort data show that year 4 students have more percentage of high level compared to two other lower cohorts, year 2 and year 3. This means that age and life experience may have positively contributed to the development of multicultural competence of the participating students.

This information shows that few of the participating students of pre-school do not have sufficient multicultural awareness and need to develop it so that they can inspire more multiculturally responsive future global citizens. This finding is also similar to those of other studies which recommend a necessary proactive measure to develop the multicultural competence of student teachers (Cross, Bazron, Dennis, \& Isaacs, 1989; Carlos, 2011) particularly for prospective preschool teachers. Without this initiative, the multicultural competence of these Muslim participants (majority religion group) may not appropriately develop, thus, hampering the increasingly diverse but harmonious Indonesia.

\section{Knowledge of Multicuralism}

Multicultural awareness should be supported by sufficient knowledge. Acquition of multicultural knowledge is more important for prospective preschool teachers. To cope with the challenge of teaching preschool children in the $21^{\text {st }}$ century, the participants need involvement in a comprehensive training for developing their multicultural competence. Since their young students will live in a moreculturally diverse future global citizens, the training they need to attend should include some essential values and basic principles of multicultural competence as well as its developmental approaches (Spanierman \& Poteat, 2005; Baruth \& Manning, 2012; Sommers, 2008). The training should facilitate the participating prospective preschool teachers to acquire and develop individual awareness on the importance of their own cultural values and knowledge, personal sensitiveness to the cultural background of their future students as well as develop skills to appreciate and accommodate students' cultural background in their learning process for more harmonious diversity (Gay, 2010; Baruth \& Manning, 2012). Prospective preschool teachers should learn about and legitimize students' diverse cultural heritages (Lind \& McKoy, 2016).

Working in a culturally diverse country, prospective preschool teachers in Indonesia are highly required to develop their multicultural knowledge. They should be able to prepare young future citizens to understand the cultural diversity of Indonesian population and respect it as a valuable source of development, not as a dividing factor. Prospective preschool teachers should develop both multicultural capability and ability through natural interaction, education and training (Cates, et. al., 2007). This competence emphasizes the importance of awareness as attitudes to multicultural difference, knowledge and skills. Supporting this notion, Sue \& Sue (2003) also argue that multicultural competence should include awareness, knowledge, and skills. As member of majority religion, one female participant of year 4 expressed personal awareness of multiculturalism. She said, You know, I don't have experience of teaching non-Muslim children. I did my teaching practicum at an Islamic preschool, so all my students have the same religion like me. So, we included some Islamic teachings into our daily activities such as reciting Qur'an, observing prayers, and other rituals. I think I have to change my practice if I teach at a public preschool. Because not all students may be Muslims.

In addition to knowledge, prospective preschool teachers of majority religion affiliation like Indonesian Muslims will be able to develop knowledge on how to respect and appreciate diversity, as well as incorporate multiculturally responsive teaching and learning strategies in their classrooms (Gay, 2010; Baruth \& Manning, 2012).

In addition to this, findings also reveal different multicultural knowledge across 
participating cohorts. As results of differential test, there is a significant difference between the cultural knowledge of year 2 and 3 students and their seniors (years 4 students). Due to their relatively shorter study length at university, the junior students may have not enough exposure to multicultural environment so that they have lower multicultural knowledge than their senior counterparts. This limited exposure to multicultural practices may hamper the development of their multicultural self-efficacy, making them less confident to be involved in multicultural encounters and strongly hold to their own ethnic identity, including Islam as their religious affiliation. In this case, some scholars such as Sodowsky, Kuo-Jackson, Richardson, \& Corey (1998); Linwood, et. al. (2008); Sommers (2008); and Hays \& Erford (2010) propose some factors which influence the development of multicultural knowledge that learners, including pre-school student teachers, need to be exposed. These factors include multicultural social desirability, ethnic identity development, self-efficacy to multicultural encounters, and multicultural empathy. These majority teachers may not have experienced teaching students who come from different ethnic and religion affiliations so that they show less empathy to 'other people' of different social and cultural groups. In Indonesian context, the need for more exposure to multicultural interaction is strong predictor for the development of multicultural competence (Budiman, 2016). One female participant argues,

Now I realize that I have to introduce my students to different cultures and religions. For example, for my Muslim students, I should introduce them to the culture of other religions such as Christian, Hindu, and Budha. This knowledge of other culture is important for good understanding and respect.

\section{Skills of Multiculturalism}

Effective multicultural knowledge needs real skill or practice. Since the skill dimension of their multicultural competence tends to be lower than other dimensions, the participating students need exposure to an effective and empowering training to develop their multicultural skills. This training should be based on strong principles and approaches for the development of multicultural competence (Spanierman \& Poteat, 2005; Baruth
\& Manning, 2012; Sommers, 2008). In addition to the development of awareness and knowledge, the underlying principles of the training should also facilitate the development of participants' multicultural skills to stimulate other people (like preschool children) to develop their initial and basic multicultural competence so that they can harmoniously live within their diversity environment (Baruth \& Manning, 2012).

Within the pre-school context, this can be manifested by incorporating multicultural skills into the curriculum of preschool teacher education. As Jackson (2006) suggests, the curriculum should include approaches of counselor-client culture match, the development of logical thinking, emic and ethic, and training. To provide pre-school teachers with more emotionally developed multicultural skills, they need to be exposed to authentic multicultural learning by involving them in real encounters with children from different cultural backgrounds (Spanierman \& Poteat, 2005). For this reason, training of multicultural competence for this study participants should include real field encounters with children of different culture and religion such as Christian, Hindu and Buddhist students who are culturally different from those of the participants.

Furthermore, responding to the more increasing challenge of teaching in a more diverse population of Indonesia, it is necessary that prospective preschool teachers maintain to improve their multicultural skills. As Table 2 also shows, the weakest aspect of multicultural competence is response and interaction. This multicultural skill is the lowest compared to multicultural awareness of their own, and lower awareness of other cultures. This implies that, as followers of majority religion (Islam), beside developing awareness, the participants need to keep developing their multicultural skills and apply them in their teaching activities. In Indonesian context, they should, for example, explore more about the values of other religions followed by their students such as Christianity, Hinduism, and Buddhism. They can design curriculum which includes multicultural practices such as organizing religious and cultural celebrations and giving respects to those of others. As many previous studies have shown (Budiman, 2017; Supriatna, Budiamin, \& Budiman, 2014; Sommers, 2008), prospective 
preschool teachers need to be able to design learning activities which are responsive to multicultural background of their students. One male participant comments on his lack of multicultural skill, saying,

This is really new to me. I don't have any experience of celebrating the cultural or religious festivals of other religions. Now I think I have changed my mind. I have to include these cultural festivals into my curriculum content.

Based on the aforementioned consideration, the training to develop multicultural competence should have comprehensive design. It should have proper or gradual phases and effective strategies. The phases should include assessment of participants' initial multicultural competence, intervention for developing multicultural competence, and self-reflection and further training. Meanwhile, to have more powerful and effective results, the training should include systematic reflection, Socratic dialog, and multicultural competence. Of these, Socratic dialog is considered the most important aspect in the development of multicultural competence as it enables learners to critically understand and internalized beliefs and values of multicultural competence (Norman, 2011).

\section{Conceptual Framework of Multicultural Education}

In addition to what have been discussed above, this study also proposes a hypothetic training model to prepare the multicultural competence of prospective preschool teachers. To find more understanding on reason, essence, and substance of multicultural education in general; the following are described concepts of culturally responsive pedagogy (CRP), attitudes towards CRP, and multiculturally responsive curriculum (MRC).

\section{Culturally Responsive Pedagogy (CRP)}

As the world becomes more culturally diverse, education should accommodate this diversity. Teaching in the $21^{\text {st }}$ century requires the promotion of culturally responsive teaching as a predominant pedagogy, commonly called Culturally Responsive Pedagogy (CRP) (Childs, 2017; Walter, 2018). Bearing this diversity in mind, some scholars emphasize the need to shift from multiculturalism to multiculturally responsive teaching in all subject areas, math, science, humanities, music education, and English (Walter, 2018; Mohammadzadeh, 2009). Culturally responsive teachers should use "the cultural knowledge, prior experiences, frames of reference, and performance styles of ethnically diverse students to make learning encounters more relevant to and effective for them" (Gay, 2010, p. 31). This teaching method is expected to provide opportunities for all learners and teachers to learn about and legitimize diverse cultural heritages (Lind \& McKoy, 2016). With this, accommodation to learners' cultural background is expected to empower their learning process.

Meanwhile, most studies on multicultural education focus on White teacher domination in some developed countries such as Europe, Australia, and North America. With increasing number of migrants into this region, these predominant teachers are then trained to be more responsive to their students from nonwhite and minority groups. In relation to this, issue of dominant majority group is also relevant in the context of Indonesia, a multi ethnic and religious country. In terms of ideology, Muslim teacher is majority and other religious groups are minorities. Within this context, majority Muslim teachers should be culturally more responsive to students from minority religious affiliations. Likewise, teachers of ethnic majority should also show similar empathy for ethnically minority group. As practitioners of education and researchers of multicultural education believe that White teachers should be more empathically to students of color (Dolby, 2012; Warren, 2015a; 2015b), religious and ethnic majority teachers in Indonesia should also show high empathy to students of minority religion and ethnicity. However, teachers' understanding on the importance of empathy is not always in line with their real practice (Warren, 2018). Therefore, this scholar argues that teacher education should be able to explore pedagogical approach which can significantly accommodate, respect, and appreciate learners' cultural background.

However, the application of CRP is easier said than done. It is even more challenging for pre-service teachers who have minimum teaching experience (Fasching-Varner \& Seriki, 2012; Warren \& Talley, 2017; Young, 2010). They may have insufficient cultural knowledge, skills, dispositions, and experiences required 
to provide quality education for students who have ethnically, linguistically, ideologically, historically, politically, and economically different perspectives (Bennett, 2012; Harriott \& Martin, 2004; Trumbell, \& Pacheco, 2006). Since they may not be professionally prepared to teach these culturally, linguistically and ideologically different students (Boutte, 2012), teacher education should consequently provide these pre-service teachers to develop their CRP competence.

\section{Attitudes towards CRP}

Teachers' attitudes towards CRP is essential. This necessity is more salient when teachers come from majority while students from minority groups. Due to this different sociocultural background, majority teachers may show different attitudes towards minority students. Sometimes, teachers think that their minority students may have low academic performance (Banks, 2006; Delpit, 2003) because they usually come from low social status community group who have limited access to quality education. Such underestimation is, however, not always based on social reason, but also ideologically justified. For instance, while the majority teachers may not underestimate the academic of their minority students, these teachers may have preconceptions and misconceptions, as well as show negative attitudes about minority students and their families (Banks, 2006; Delpit, 2003). This misconception, in Indonesian context, may be experienced by majority Muslim teachers who have students from different minority ideology affiliations. Although the participating majority prospective teachers in this study may not underestimate the academic performance of their students, for instance, they have misconception about the ideological perception of their students or even ignore their existence in their classrooms.

For a good administration, CRP also needs positive attitudes from school leadership. Together with school principals, teachers become important actors in the successful implementation of culturally responsive pedagogy. Without their strong commitment and leadership, as the case in Malaysia Vision School (Malakolunthu, 2010), the program will not successfully transform into a more empowering multicultural education. As such, the success of this pedagogy application depends on strong supports from school leadership and management.
Furthermore, positive attitudes toward minority students need real practice. Multicultural content should be included into real teaching practice. Majority prospective and in-service teachers should be exposed to teaching diverse students, different from their cultural backgrounds. A study among intern/ teaching fellows in New York the United States by Cicchelli \& Cho (2007) shows that White intern/teaching fellows have more increasing awareness of diverse cultural backgrounds of their students when they are exposed to real teaching practice with multiculturally diverse students. Prospective teachers who have experienced 'critical multicultural education' tend to acquire multicultural attitudes more easily. Therefore, multicultural education content, materials, and activities should to be integrated in teacher education curriculum (Arsal, 2019).

\section{Multiculturally responsive curriculum}

As a consequence, curriculum of teachers' professional development should take into account multiculturalism. It should include teachers' active commitment to social justice, anti-oppressive, and antiracist teaching (Villegas, 2007). This concept is often called culturally responsive pedagogy (CRP), which is derived from culturally responsive teaching developed by Gay $(2010 ; 2013)$ combined with culturally relevant pedagogy by Ladson-Billing (1994; 1995; 2014). Based on CRP, teachers, who usually come from majority group, are demanded to consider students' cultural background in their teaching 'orientation, habits, and tendencies (Warren, 2018) who usually come from minority groups. To support minority students, teachers should have strong commitment to respond, understand minority behaviors, and senses of efficacy in addressing the needs of diverse students (Bonner, et. al., 2018) for education equity.

Furthermore, considering its importance, CRP is an integral part of teacher education. This concept should influence the design of curriculum. As an imperative element of multicultural education, curriculum should be designed to be responsive to the needs of culturally diverse students (Bonner, et. al., 2018). It should accommodate diversity of ethnicity, linguistics, and ideology. This response to diversity can lead to equity in education, which 
is necessary for a culturally and ideologically diverse country like Indonesia. Responding to the demand for CRP, for instance, curriculum in Taiwanese teacher-education program is reoriented to include the establishment of preservice teachers' inclusion to the development of positive attitude and meaning towards students from minority groups so that they can maintain Chinese cultural heritage (Chou, Sue, \& Wang, 2018).

Curriculum content should include appreciation to minority groups. As an effective learning strategy (Alfulailah, et. al., 2019), it enables minority students to be accommodated and respected. Appreciation includes greetings, religious celebration and avoiding offensive behaviors to minority students. In addition to intracurricular, culturally responsive curriculum also includes multicultural activities in extracurricular activities. Through out of curriculum activities, minority students are engaged in expressing their own cultural values to be acknowledged and respected (Walter, 2018; Ghufron, et. al., 2017; Wagiran, et. al., 2019).

The incorporation of multicultural content into curriculum is more common for primary education level and higher, but rare for preschool students. This is possibly because older students are more expected to be multiculturally competent than the younger ones. For instance, most curriculums of preschool teachers in Indonesian context do not include multicultural competence for prospective teachers (Budiman, 2016). In fact, as the development of multicultural competence is a lengthy and recursive process, multicultural content should be incorporated into curriculum as early as possible. As essential agents of multicultural education, prospective teachers of preschool need to be exposed to training in developing multicultural content and activities (Budiman, 2017; Supriatna, et. al., 2014; Spanierman Poteat, 2005; and Sommers, 2008) so that they can become multiculturally responsive and competent preschool teachers (Vereen, Hill, \& McNeal, 2008; Ridley, Mendoza, Kanitz, Angermeier, \& Zenk, 1994).

\section{CONCLUSION}

Research finding indicates that the majority of participants have high level of multicultural competence and only a small percentage have moderate level of competence. Although, the participants generally shows high level in their multicultural competence, in certain aspects are still needed to be improved. They still need to raise their awareness on social justice, prejudice and preconceptions on students from different cultural and ideological background. They also need to improve their competence in developing multiculturally responsive teaching and learning strategies so that they can accommodate the needs of their diverse students.

To develop students' multicultural competence, especially for whom with low level of the multicultural competence, they could attend a training on multicultural competence as designed through this study. This training model is designed to prepare prospective preschool teachers to develop their multicultural competence. The training consists of three phases: assessment of multicultural competence, intervention program for multicultural competence, and reflection for further activity. There are six steps of the intervention program, namely systematic reflection, Socratic dialog, simulation, field practice, and reflection. The training model includes a guide book for organizing prospective pre-school teacher training and another guide book for implementing the training on multicultural competence.

Meanwhile, the study also recommends to test and analyze the effectiveness of this newly designed model in developing the multicultural competence of prospective preschool teachers.

\section{REFERENCES}

Alfulailah, N., Haryadi, Sudrajat, A., \& Nasrullah. (2019). The effectiveness of multicultural approach in writing achievement of Indonesian language. Cakrawala Pendidikan, 38(2), 1-15. doi:10.21831/cp.v38i2.23440.

Arsal, Z. (2019). Critical multicultural education and prospective teachers' multicultural attitudes. Journal for Multicultural Education, 13(1), 106118. doi:10.1108/JME-10-2017-0059.

Banks, J.A. (2006). Race, culture, and education: The selected works of James A. Banks. London, England: Routledge.

Baruth, L. G. \& Manning, M. L. (2012). Multicultural counseling and 
psychotherapy: A life span approach. Hoboken, NJ: Pearson Education.

Bennett, S. V. (2012). Effective facets of a field experience that contributed to eight prospective teachers' developing understandings about culturally responsive teaching. Urban Education, 48(3), 380419. doi: $10.1177 / 0042085912452155$. Bidell, M. P. (2012). Examining school counseling students' multicultural and sexual orientation competencies through a cross-specialization comparison. Journal of Counseling and Development, 90(2), 200-207. doi:10.1111/j.15566676.2012.00025.x.

Blodorn, A., O’Brien, L. T., Cheryan, S., \& Vick, S. B. (2016). Understanding perceptions of racism in the aftermath of hurricane Katrina: The roles of system and group justification. Social Justice Journal, 29(2), 139-158. doi:10.1007/s11211-0160259-9.

Bonner, P. J., Warren, S. R., \& Jiang, Y. H. (2018). Voices from urban classrooms: Teachers' perceptions on instructing diverse students and using culturally responsive teaching. Education and Urban Society, 50(8), 697726. doi:10.1177/0013124517713820.

Boutte, G. S. (2012). Urban schools: Challenges and possibilities for early childhood and elementary education. Urban Education, 47(2), 515-550. doi:10.1177/0042085911429583.

Budiman, N. (2016). Pendidikan profesional konselor multibudaya (Studi pengembangan pendidikan profesional konselor berbasis kompetensi multibudaya) (Doctoral dissertation, Sekolah Pascasarjana UPI).

Budiman, N. (2017, November). Competences of the 21 st century: The development of multicultural counselor competences. Proceedings of the 1st International Conference on Educational Sciences, Bandung, West Java, Indonesia, 310-314.
Carlos, P. H. (2011). Developing counseling students'multiculturalcompetencethrough the multicultural action project. American Counseling Association Journal, 3(50), 402-420. doi:10.1002/j.1556-6978.2011. tb01924.x.

Cates, J. T., Schaefle, S. E., Smaby, M. H., Maddux, C. D., \& Beauf, I. L. (2007). Comparing multicultural with general counseling knowledge and skill competency for students who completed counselor training.Journal of Multicultural Counseling and Development: American Counseling Association, 35(1), 26-39. doi:10.1002/j.2161-1912.2007.tb00047.x.

Childs, K. (2017). Integrating multiculturalism in education for the 2020 classroom: Moving beyond the "melting pot" of festivals and recognition months. Journal for Multicultural Education, 11(1), 31-36. doi:10.1108/JME-062016-0041.

Chou, P. I, Sue, M. H. \& Wang, Y., T. (2018). Transforming teacher preparation for culturally responsive teachers in Taiwan. Teaching and Teacher Education, 75, 116127. doi:10.1016/j.tate.2018.06.013.

Cicchelli, T. \& Cho, S. J. (2007). Teacher multicultural attitudes: intern/teaching fellows in New York city. Education and Urban Society, 39(3), 370-381. doi:10.1177/0013124506298061.

Cornish, J. A. E., Schreier, B. A., Nadkarni, L. I., Metzger, L. H., \& Rodolfa, E. R. (2010). Handbook of multicultural counseling competencies. Hoboken, NJ: John Wiley \& Sons.

Cross, T., Bazron, B., Dennis, K., \& Isaacs, M., (1989). Towards a culturally competent system of care, Volume I. Washington, DC: Georgetown University Child Development Center, CASSP Technical Assistance Center. 
Delpit, L. (2003). Educators as "seed people" growing a new future. Educational Researcher, 32(7), 14-21. doi:10.3102/0013189X032007014.

Dolby, N. (2012). Rethinking multicultural education for the next generation: The new empathy and social justice. New York, NY: Routledge.

Enoksen, E. \& Sandal, G. M. (2015). Anxietybased personal values and perceived organizational justice. Social Justice Journal, 4(28), 479-492.

Farozin, M. (2019). Counselor professional identity of counselor profession education Cakrawala Pendidikan, 38(1), 104-119. doi:10.21831/cp.v38i1.22515.

Fasching-Varner, K. J., \& Seriki, V. D. (2012). Moving beyond seeing with our eyes wide shut: A response to "There is no culturally responsive teaching here". Democracy \& Education, 20(1), 1-6.

Gay, G. (2010). Culturally responsive teaching: Theory, research, and practice (2nd ed.). New York, NY: Teachers College Press.

Gay, G. (2013). Teaching to and through cultural diversity. Curriculum Inquiry, 43(1), 4870. doi:10.1111/curi.12002.

Ghufron, A., Budiningsih, C. A., \& Hidayati. (2017). Developing instructional model based on cultural values of Yogyakarta at Primary School. Cakrawala Pendidikan, 38(2), 309-319. doi:10.21831/ cp.v36i2.12449.

Harriott, W. A., \& Martin, S. S. (2004). Using culturally responsive activities to promote social competence and classroom community. Teaching Exceptional Children, 37(1), 48-54. doi:10.1177/004005990403700106.

Hays, D. G., \& Erford, B. T. (2010). Developing multicultural competence: A system approach. New Jersey, NJ: Pearson Education.
Jackson, Y. (2006). Encyclopedia of multicultural psychology. California, CA: Routledge Taylor \& Francis Group.

Kagnıc1, D. Y. (2011). Teaching multicultural counseling: An example from a Turkish counseling undergraduate program. Eurasian Journal of Educational Research, 2 (44), 111-128.

Ladson-Billings, G. (1994). The dreamkeepers: Successful teachers of African American children. San Francisco, CA: JosseyBass.

Ladson-Billings, G. (1995). Toward a theory of culturally relevant teaching. American Educational Research Journal, 32(3), 465491. doi:10.3102/00028312032003465.

Ladson-Billings, G. (2014). Culturally relevant pedagogy 2.0: A.k.a. the remix. Harvard Educational Review, 84(1), 74-84. doi:10.17763/ haer.84.1.p2rj131485484751.

Lind, V. R., \& McKoy, C. L. (2016). Culturally responsive teaching in music education: From understanding to application. New York, NY: Routledge.

Linwood, G. V., Nicole R. H., \& Donell T. M. (2008). Perceptions of multicultural counseling competency: integration of the curricular and the practical. Journal of Mental Health Counseling, 2(30), 226-236. doi:10.17744/ mehc.30.3.g34u122m16q64g44.

Malakolunthu, S. (2010). Culturally responsive leadership for multicultural education: The case of "Vision School" in Malaysia. Procedia Social and Behavioral Sciences, 9, 1162-1169. doi:10.1016/j. sbspro.2010.12.301.

Mohammadzadeh, B. (2009). Incorporating multicultural literature in English language teaching curriculum. ProcediaSocial and Behavioral Sciences, 1(1), 23-27. doi:10.1016/j.sbspro.2009.01.008. 
Norman, A. (2011). The Socratic method as an approach to learning and its benefits. Pittsburgh, PA: Carnegie Mellon University Press.

Norman, E. (2000). Resiliency enhancement: Putting the strengths perspective into social work practice. New York, NY: Columbia University Press.

Perkins, D. M. \& Mebert, J. M. (2005). Efficacy of multicultural education for preschool children a domainspecific approach. Journal of CrossCultural Psychology, 36(4), 497-512. doi:10.1177/0022022105275964

Ridley, C. R., Mendoza, D. W., Kanitz, B. E., Angermeier, L., \& Zenk, R. (1994). Cultural sensitivity in multicultural counseling: A perceptual schema model. Journal of Counseling Psychology, $41(2), \quad 125-136 . \quad$ doi:10.1037/00220167.41.2.125.

RoI, Setjen MPR RI. (2012). Empat pilar kehidupan berbangsa dan bernegara. Jakarta: MPR RI.

Sodowsky, G. R., Kuo-Jackson, P.Y., Richardson, M. F., \& Corey, A. T. (1998). Correlates of self-reported multicultural competencies: counselor multicultural social desirability, race, social inadequacy, locus of control racial ideology, and multicultural training. Journal of Counseling Psychology, 45(3), 256-264. doi:10.1037/00220167.45.3.256.

Sommers, D. K. (2008). The development of multicultural counseling competencies by utilizing service learning (Doctoral dissertation, University of MissouriSt. Louis). from https://irl.umsl.edu/ dissertation/527.

Spanierman, L.B. \& Poteat, V.P. (2005). Moving beyond complacency to commitment: Multicultural research in counseling psychology. Journal of the Counseling Psychologist. 33 (4), 513-523. doi: $10.1177 / 0011000005276469$.
Sue, D. W., \& Sue, D. (2003). Counseling the culturally diverse: Theory and practice ( $4^{\text {th }}$ ed.). Hoboken, NJ: John Wiley \& Sons.

Supriatna, M., Budiamin, A., \& Budiman, N. (2014). Pengembangan bimbingan dan konseling berbasis kompetensi multibudaya peserta didik (Research Report). Bandung: LPM UPI.

Trumbell, E., \& Pacheco, M. (2006). Leading with diversity: Cultural competencies for teacher preparation and professional development. Providence, RI: The Education Alliance at Brown University.

Vereen, L. G., Hill, N. R., \& McNeal, D. T. (2008). Perceptions of multicultural counseling competency: Integration of the curricular and the practical. Journal of Mental Health Counseling, 3(30), 226-236. doi:10.17744/ mehc.30.3.g34u122m16q64g44.

Villegas, A. M. (2007). Dispositions in teacher education: A look at social justice. Journal of Teacher Education, 58(5), 370-380. doi: $10.1177 / 0022487107308419$.

Wagiran, W., Pardjono, P., Suyanto, S., Sofyan, H., Soenarto, S., \& Yudantoko, A. (2019). Competencies of future vocational teachers: perspective of inservice teachers and educational experts. Cakrawala Pendidikan, 38(2), 387-397. doi:10.21831/cp.v38i2.25393.

Walter, J. S. (2018). Global perspectives: Making the shift from multiculturalism to culturally responsive teaching. General Music Today, 31(2), 24-28. doi:10.1177/1048371317720262.

Warren, C. A. (2015a). Conflicts and contradictions: Conceptions of empathy and the work of goodintentioned White female teachers. Urban Education, 50(5), 572-600. doi:10.1177/0042085914525790. 
Warren, C. A. (2015b). Scale of Teacher Empathy for African American Males (S-TEAAM): Measuring teacher conceptions and the application of empathy in multicultural classroom settings. Journal of Negro Education, 84(2), 154-174. doi:10.7709/ jnegroeducation.84.2.0154.

Warren, C. A. (2018). Empathy, teacher dispositions, and preparation for culturally responsive pedagogy. Journal of Teacher Education, 69(2), 169-183. doi:10.1177/0022487117712487.
Warren, C. A., \& Talley, L. M. (2017). "Nice White Ladies": Race, whiteness, and the preparation of White female teachers to be culturally responsive educators. In S. D. Hancock \& C. A. Warren (Eds.), White women's work: Examining the intersectionality of teaching, identity, and race (pp. 147-175). Charlotte, NC: Information Age.

Young, E. (2010). Challenges to conceptualizing and actualizing culturally relevant pedagogy: How viable is the theory in classroom practice. Journal of Teacher Education, 61(3), 248-260. doi: $10.1177 / 0022487109359775$. 